\title{
STUDI KUAT LENTUR PELAT FERROCEMENT DENGAN LAPISAN LEMBARAN ALUMINIUM SEBAGAI BEKISTING TETAP PADA MATERIAL PELAT LANTAI BANGUNAN BERTINGKAT
}

\author{
Ali Rahman, Gina Bachtiar, Daryati
}

\begin{abstract}
This study aims to find out, What is the value generated by the flexural strength ferosemen plate using aluminum formwork. This study tries to explain through experiments testing flexural strength ferosemen plate using aluminum sheets as formwork can produce a large flexural strength so that this material will be used as an alternative material storey building floor plate structure. This study using experimental methods, the population is ferosemen concrete slab specimens using aluminum formwork with dimensions of $0.3 \mathrm{~mm}$ length of $1100 \mathrm{~m}$, width $300 \mathrm{~mm}$, and thickness $50 \mathrm{~mm}$. The sample used is a plate-shaped test piece of 15 specimens with three groups of mix proportions and FAS 0.45 , the 5 pieces of specimen mix 1 Pc: 2 Ps; 5 pieces of specimen mix 1 Pc: 3 Ps: and 5 pieces of the test object with a mixture of $1 \mathrm{Pc}: 4 \mathrm{Ps}$. Overall the test object using a 2 layered ferosemen woven wire reinforcement. the results obtained for the average value of flexural strength of ferrocement concrete slab using aluminum sheet as a permanent formwork is the best 28 days in a mixture of 1 PC: 3 Ps of $42.91 \mathrm{~kg} / \mathrm{cm} 2$, while the flexural strength values in the mixture 1 PC: 2 Ps of $37.66 \mathrm{~kg} / \mathrm{cm} 2$, and a PC: 4 Ps of $36.66 \mathrm{~kg} / \mathrm{cm} 2$. The results for the average value of modulus of elasticity (MOE) test 28 days old, on a mixture of a 1 PC: 2 Ps of $50.626,55 \mathrm{Kg} / \mathrm{cm}^{2}$, a mixture of 1 PC: 3 Ps of $51.602,52 \mathrm{~kg} / \mathrm{cm}^{2}$, and a mixture of $1 \mathrm{PC}$ : $4 P s$ of $39.198,77 \mathrm{Kg} / \mathrm{cm}^{2}$.
\end{abstract}

Keywords : ferosemen, aluminium formwork, the results of flexural strength of ferosemen

\begin{tabular}{|l|c|r|}
\hline Ali Rahman & DR.Gina Bachtiar, MT & Dra. Daryati, MT \\
Alumni Jurusan Teknik Sipil & Staff Pengajar Jurusan Teknik Sipil \\
Fakultas Teknik & Fakultas Teknik & Staff Pengajar Jurusan Teknik Sipil \\
Universitas Negeri Jakarta, 13220 & Fakultas Teknik \\
& $\begin{array}{c}\text { Universitas Negeri Jakarta, 13220 } \\
\text { email : ginbach@yahoo.com }\end{array}$ & $\begin{array}{c}\text { Universitas Negeri Jakarta, 13220 } \\
\text { email : daryati_sr@ymail.com }\end{array}$ \\
\hline
\end{tabular}




\section{PENDAHULUAN}

Dewasa ini jenis-jenis teknologi pelat lantai yang umumnya digunakan pada gedung bertingkat adalah pelat konvensional, pelat bondek (floor deck) dan pelat beton pracetak. Pelat konvensional merupakan pelat lantai beton bertulang yang dicetak dengan menggunakan bekisting dan perancah, kemudian diberi tulangan dan dicor dengan beton mutu tertentu. Setelah pelat lantai berumur sekian hari, bekisting dan perancah dilepas. Pelat bondek adalah sejenis pelat baja mutu tinggi yang berfungsi sebagai bekisting tetap sekaligus sebagai penulangan positif (Union Metal, 2006). Pelat beton pracetak adalah pelat beton berongga dengan penulangan yang telah diberi tegangan awal yang telah dicetak atau diproduksi di pabrik (Dantosan Precon Perkasa, 2006).

Secara visual lembaran plat bondek mirip dengan lembaran plat aluminium. Perbedaanya terletak pada bahan dasar baja mutu tinggi dengan tonjolan-tonjolan embos serta desain sambungan pada plat bondek yang tidak terdapat pada plat aluminium. Dalam pelaksanaan konstruksi di lapangan yang pernah saya lihat pada saat melaksanakan kegiatan Praktek Kerja Lapangan (PKL) pada proyek pembangunan Pengadilan Negeri Jakarta Timur 2010 lalu, kadang timbul pertanyaan apakah plat aluminium jika dibuat dengan tonjolan-tonjolan embos dan dikonstruksikan sedemikian rupa dapat berfungsi sebagai plat bondek. Berkaitan pula dengan mahalnya harga material bahan bangunan yang berdampak pada semakin tingginya biaya konstruksi saat ini, maka alternatif penggunaan material yang ekonomis dan efisien perlu dikembangkan. Salah satunya adalah penggunaan aluminium dan ferosemen sebagai material pada pelat lantai bangunan.

Pertimbangan digunakannya lembaran aluminium adalah karena aluminium merupakan bahan logam ringan yang mudah ditemukan disetiap toko material dan sekaligus dapat berfungsi sebagai cetakan yang menambah kekuatan tarik ferosemen. Selain itu penggunaan bahan aluminium ini dipilih karena menindak lanjuti penelitian sebelumnya yang dilakukan oleh Setiyarto dengan judul penelitian "Penggunaan Ferosemen dan Plat Seng Sebagai Material Pelat Lantai Bangunan Bertingkat untuk Menekan Biaya Konstruksi”. Dimana sesuai hasil penelitian yang dipaparkan beliau menyarankan agar dilakukan penelitian sejenis dengan menggunakan bahan aluminium. 
Ferosemen sendiri merupakan material komposit dengan bahan yang terbuat dari campuran pasir dan semen dengan menggunakan kawat-kawat jala yang dapat membentuk suatu kesatuan yang utuh dan membentuk konstruksi yang cukup kuat. Tebal ferosemen pada umumnya berkisar antara $10 \mathrm{~mm}$ hingga $50 \mathrm{~mm}$ dengan volume tulangan berkisar antara $6 \%$ hingga $8 \%$ dari seluruh isi konstruksi.

Aplikasi ferosemen telah banyak diimplementasikan pada berbagai macam struktur bangunan yang ada di wilayah Indonesia. Aplikasi tersebut antara lain perumahan atau mesjid seperti pada Masjid Al-Abror di Bandar Lampung, bangunan monumental seperti gerbang utama Kebun Binatang Ragunan dan Menara Siger di Bakauheni - Lampung, dan struktur - struktur untuk resapan air lainnya (Anshori Djausal dikutip dalam Lampung Post, 1999). Ferosemen merupakan teknologi alternatif yang ekonomis. Teknologi ini dapat dimanfaatkan sebagai bahan bangunan maupun bahan untuk membuat pesawat ruang angkasa sekalipun. Dibandingkan dengan beton bertulang, ferosemen lebih tipis, memiliki tulangan yang terdistribusi pada setiap ketebalannya, penulangan dua arah, dan matriksnya hanya terdiri atas agregat halus dan semen. Namun diakui ferosemen kurang populer dibandingkan dengan beton bertulang, hal ini disebabkan sifatnya yang ekonomis sehingga pelaku konstruksi yang berorientasi pada proyek besar menjadi tidak tertarik (Anshori Djausal dikutip dalam Lampung Post, 1999).

Pelat lantai merupakan elemen struktural terbesar dari sistem struktur bangunan bertingkat yang secara langsung menopang beban. Apabila alternatif material yang ekonomis dan efektif untuk pelat lantai dapat digunakan, maka dapat diperkirakan total biaya proyek akan berkurang secara signifikan. Hal tersebut memungkinkan diadakannya pembangunan gedung bertingkat yang ekonomis sebagai salah satu cara mengatasi mahalnya harga material bangunan terutama daerah perkotaan.

Berdasarkan uraian-uraian diatas, maka dalam penelitian ini peniliti akan membahas tentang penggunaan aluminium yang diharapkan dapat berfungsi seperti plat bondek, dan ferosemen yang dicetak terlebih dahulu bersama-sama dengan plat aluminium dalam lembaran-lembaran pelat tipis diharapkan dapat berfungsi sebagai pelat lantai. Atas dasar pemikiran tersebut maka diharapakan penelitian yang berjudul "Studi Kuat Lentur Pelat Ferosemen dengan Lapisan Lembaran Aluminium Sebagai Bekisting Tetap Pada 
Material Pelat Lantai Bangunan Bertingkat" ini nantinya dapat bermanfaat dan membantu dalam mengupayakan perencanaan konstruksi yang lebih ekonomis dan aman.

\section{Pengertian Beton Ferosemen}

Definisi ferosemen sebagai bahan konstruksi disimpulkan oleh American Concrete Institute (ACl) Commite 549 sebagai berikut, "Ferosemen is a type of thin wall reinforced concrete construction where usually a hydraulic cement is reinforced with layer of continous and relatively small diameter mesh. Mesh may be made of metallic material or other suitable materials." (Ferosemen adalah semacam konstruksi beton bertulang tipis, dimana biasanya semen hidrolis diperkuat dengan lapisan-lapisan kawat anyaman yang berdiameter kecil dan menerus. Lapisan kawat anyaman dapat terbuat dari bahan metal atau bahan lain yang cocok digunakan).

\section{Bahan Pembentuk Ferosemen}

Menurut Antoine. E Naman (former chairman of American Concrete Institue Commite 549) campuran hidrolis untuk ferosemen harus direncanakan menurut standar prosedur mix design untuk mortar dan beton. Pada umumnya mortar ferosemen terdiri dari semen portland, pasir halus, air, dan admixture tambahan lainnya. Untuk lebih jelasnya mengenai bahan pembentuk ferosemen, maka material pembentuk ferosemen berdasarkan ACI 549 Chapter 3-Materials Requirements dapat dijabarkan sebagai berikut:

\section{Semen Portand,}

Semen yang digunakan dalam pembuatan ferosemen adalah semen portland, berupa bahan hidrolik yang berfungsi sebagai perekat diantara bahan-bahan penyusun lainnya. Semen ini dibuat dari serbuk halus mineral kristalin dengan komposisi utama adalah kalsium dan aluminium silikat, penambahan air pada mineral ini akan membentuk suatu pasta yang jika mengering akan mempunyai kekuatan seperti batu.

Kekuatan yang dihasilkan oleh semen portland merupakan proses hidrasi, dimana dalam proses kimiawinya akan berupa rekristalisasi dalam bentuk kristalkristal yang saling mengunci, sehingga membentuk gel semen yang mempunyai kekuatan tinggi apabila mengeras. 
Semen Portland yang memenuhi syarat sesuai SNI 16-2049-2004 atau standar uji bahan bangunan yang telah diakui lainnya. Semen harus segar, konsistensi seragam, dan bebas dari benjolan asing, serta harus disimpan ditempat yang kering dan dala waktu yang sesingkat mungkin.

\section{Agregat,}

Agregat adalah material inti dari beton dengan fungsi sebagai pengisi. Untuk beton ferosemen agregat yang digunakan adalah agregat halus, dikarenakan ukuran ferosemen yang berkisar antara $10 \mathrm{~mm}$ sampai dengan $50 \mathrm{~mm}$. Agregat halus yang digunakan harus sesuai dengan Standar Nasional Indonesia (SNI 1970:2008) yang diadopsi dari Standar Industri Indonesia (SII) 0052-80 atau American Standard For Testing Material (ASTM) C 330 atau standar uji bahan bangunan yang diakui lainnya. Agregat harus bersih, bebas dari material organik dan zat merugikan lainnya.

Fungsi dari agregat adalah sebagai bahan pengisi yang akan membentuk mortar dengan dicampur air dan semen, dimana pasir harus lolos dari saringan no. 4 dan tertahan pada saringan no. 100 saringan standar Amerika. Agregat ini tidak boleh mengandung zat organik yang berlebihan, untuk itu maka agregat harus dibuktikan dengan pengujian menggunakan larutan $\mathrm{NaOH} 3 \%$ sehingga menghasilkan warna standar yang diperbolehkan. American Concrete Institute ( $\mathrm{ACl})$ Commite 304 memberikan standar penggunaan pasir yang lolos saringan no $50(0,30$ $\mathrm{mm}$ ) berkisar antara $15 \%$ sampai dengan $30 \%$. Namun bagaimanapun, ukuran partikel maksimum harus dikontrol oleh kendala konstruksi seperti ukuran jaringan kawat dan jarak antar jaringan kawat.

Mutu suatu agregat ditentukan oleh kandungan lumpur yang bercampur dan ikut pada saat pengambilan dari sumber penambangan material. Semakin sedikit lumpur yang terkandung didalam agregat maka semakin baik agregat digunakan untuk bahan campuran beton. Berhubungan dengan kandungan kadar lumpur agregat, sesuai dengan SNI 1970:2008 dinyatakan bahwa jumlah kandungan lumpur yang diijinkan dalam agregat halus adalah maksimal $5 \%$ dari seluruh berat agregat karena bila terlalu banyak akan sangat berpengaruh terhadap kekuatan beton. 
Tabel 1. Gradasi Ageregat Halus Beton Ferosemen

\begin{tabular}{|cc|c|}
\hline \multicolumn{2}{|c|}{ Ukuran saringan standar (mm) } & \% lewat \\
\hline $3 / 8 ”$ & $(9,50)$ & 100 \\
\hline No. 4 & $(4,75)$ & $95-100$ \\
\hline No. 8 & $(2,36)$ & $80-100$ \\
\hline No. 16 & $(1,18)$ & $50-85$ \\
\hline No. 32 & $(0,60)$ & $25-60$ \\
\hline No. 50 & $(0,30)$ & $10-30$ \\
\hline No. 100 & $(0,15)$ & $2-10$ \\
\hline
\end{tabular}

3. Air,

Air sesuai standar $\mathrm{ACl}$ Commite 549. Air yang digunakan dalam campuran mortar harus bersih, dan tidak megandung zat kimia merugikan. Air harus terbebas dari material organic, lumpur, minyak, gula, klorida, dan zat asam. Air harus memiliki pH $\leq$ 7 untuk meminimalkan penurunan $\mathrm{pH}$ dari bubur mortar dan air tidak diperbolehkan menggunakan air yang mengandung garam. Selain itu, air dan semen akan terjadi reaksi kimia, maka diperlukan perbandingan atau faktor air semen yang baik yang akan menghasilkan kualitas beton yang baik.

4.Proporsi Campuran,

Perencanaan proporsi campuran mengacu pada $\mathrm{ACl}$ Commite 549 in design, Construction, and Repair of Ferosemen dimana kisaran proporsi yang direkomendasikan untuk aplikasi ferosemen umumnya perbandingan campuran berdasarkan berat untuk ferosemen yang dianjurkan adalah rasio pasir dan semen $(\mathrm{S} / \mathrm{C})$ berada pada 1,5 - 2,5 serta untuk rasio air dan semen (W/S) sekitar 0,35 - 0,5.

\section{Tulangan,}

Tulangan pada beton digunakan untuk menahan gaya-gaya yang bekerja pada beton, baik itu pembebanan, puntir, maupun lentur yang akan mengakibatkan retak dan patah pada beton (Sulaeman, 2005). Penulangan pada beton ferosemen hanya menggunakan kawat anyaman atau kawat jala. 
Kawat anyaman atau kawat jala merupakan salah satu bahan pengisi beton ferosemen. Fungsi dari kawat ini adalah untuk membuat bentuk beton yang diinginkan dan menyerap tegangan-tegangan tarik pada konstruksi. Jumlah lapisan kawat anyam ini umumnya 2 lapis sampai dengan 8 lapis sesuai dengan perencanaan (Sulaeman, 2005).

Menurut $\mathrm{ACl} 549$ Chapter 3-Materials Requirements menyatakan bahwa kawat anyam umumnya memiliki bukaan hexagonal atau persegi. Kawat anyaman dengan bukaan hexagonal kadang-kadang disebut sebagai kawat kandang ayam atau kandang burung. Struktur kawat anyaman hexagonal tidak seefisien kawat anyaman persegi karena jaring kawat tidak selalu berorientasi pada arah tegangan utama (maksimum). Namun sangat fleksibel dan dapat digunakan dalam elemen ganda melengkung.

Dalam penelitian ini, kawat anyaman yang digunakan adalah kawat anyam berbentuk persegi, dengan diameter $0,5 \mathrm{~mm}-1 \mathrm{~mm}$ dengan jarak antar lubang sebesar $10 \mathrm{~mm}-25 \mathrm{~mm}$. Hal ini dipilih karena mudah dalam pengerjaan benda uji, mudah ditemukan dipasaran, dan harganya tidak terlalu mahal..

\section{Kekuatan Lentur (Modulus of Rupture)}
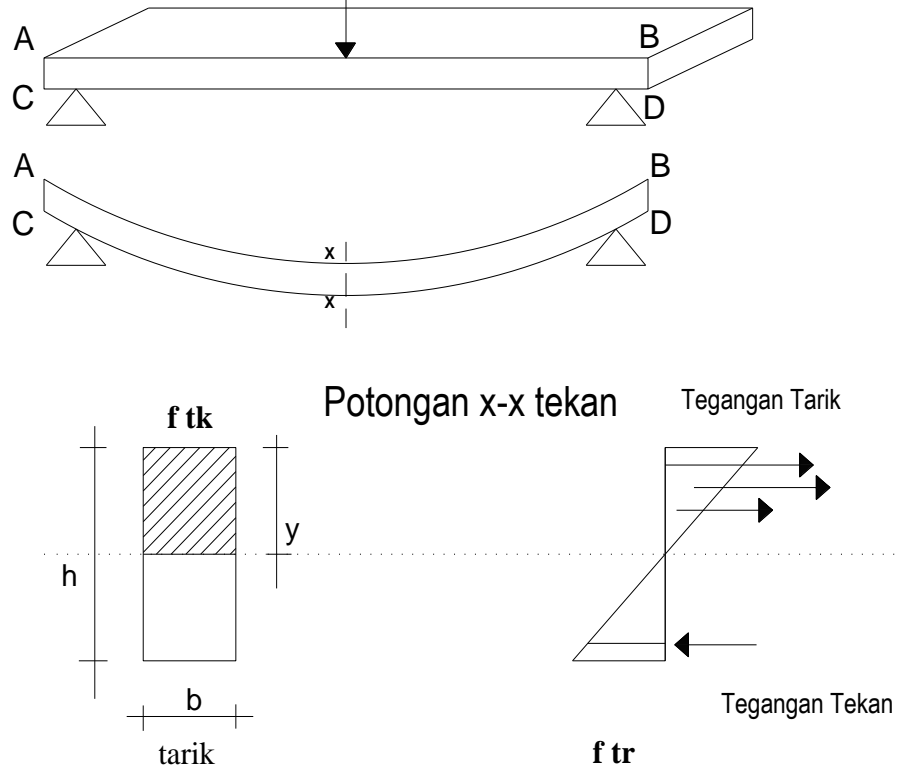

Gambar 1 Lentur pada beton 
Kekuatan lentur adalah kemampuan yang dimiliki oleh benda yang diletakkan pada dua perletakan untuk menahan gaya dalam arah tegak lurus sumbu benda uji yang diberikan padanya, sampai benda uji patah. Beban yang bekerja tersebut dapat berupa beban gravitasi atau beban lain seperti angin, susut, dan perubahan lentur yang dapat menyebabkan terjadinya lentur dan deformasi pada elemen struktur. Lentur terjadi akibat adanya regangan yang timbul akibat beban luar seperti pada Gambar 1.

Beban luar yang bekerja pada suatu bidang, bila sudah maksimal akan mengakibatkan perubahan pada struktur. Bagian daerah atas akan mengalami gaya tekan sedangkan bagian bawah akan mengalami gaya tarik. Pada bagian daerah tarik, bila beban terus ditambah sedikit demi sedikit secara konstan akan menimbulkan retak dan bila beban sudah maksimal maka akan terjadi patahan.

Definisi dari kuat lentur sendiri menurut SNI 03-4431-1997 tentang Metode Pengujian Kuat Lentur Normal Dengan Dua Titik Pembebanan adalah kemampuan balok beton yang diletakkan pada dua perletakan untuk menahan gaya dengan arah tegak lurus sumbu benda uji yang diberikan padanya, sampai benda uji patah dan dinyatakan dalam satuan Mega Pascal (Mpa) gaya tiap satuan luas.

Berdasarakan SNI 03-2823-1992 tentang "Metode Pengujian Kuat Lentur Beton Memakai Gelagar Sederhana dengan Sistem Beban di Tengah" ditetapkan rumus perhitungan kuat lentur yaitu :

$$
\begin{aligned}
\sigma \text { lt } & =\frac{M}{W} \\
\sigma \text { lt } & =\frac{\frac{1}{4} P \times L}{\frac{1}{6} b \times \mathrm{h}^{2}} \\
\sigma \mathrm{lt} & =\frac{3 P \times L}{2 b \times \mathrm{h}^{2}}\left(\mathrm{Kg} / \mathrm{cm}^{2}\right)
\end{aligned}
$$

dengan :

$\sigma \mathrm{lt}=$ kuat lentur $\left(\mathrm{kg} / \mathrm{cm}^{2}\right)$,

$\mathrm{P} \quad=$ beban bekerja $(\mathrm{kg})$,

$\mathrm{L} \quad=$ jarak antar tumpuan $(\mathrm{cm})$,

$\mathrm{b} \quad=$ lebar benda uji $(\mathrm{cm})$

$\mathrm{h} \quad=$ tebal benda uji $(\mathrm{cm})$ 


\section{Modulus Elastisitas Beton (Modulus of Elasticity)}

Kuat lentur adalah kekuatan untuk menahan gaya-gaya yang berusaha melengkungkan bahan atau menahan beban-beban mati maupun yang hidup selain beban pukulan yang harus dipikul oleh bahan tersebut (Yeni Raini, 2011). Modulus elastisitas beton dipengaruhi oleh jenis agregat, kelembaban benda uji beton, faktor air semen, umur beton dan temperaturnya. Secara umum, peningkatan kuat tekan beton seiring dengan peningkatan modulus elastisitasnya. Menurut pasal 10.5 SNI-03-2847 (2002) hubungan antara nilai modulus elastisitas beton normal dengan kuat tekan beton adalah $E c=4700 \sqrt{ } \mathrm{c}$. Sedangkan untuk beton dengan berat jenis (Wc) $1500 \mathrm{~kg} / \mathrm{m}^{3}-2500 \mathrm{~kg} / \mathrm{m}^{3}$ dapat diambil nilai modulus elastisitas sebesat $(\mathrm{Wc})^{1,5} 0,043 \sqrt{ } \mathrm{C}$.

$$
\mathrm{MOE}=\frac{\Delta P \times \mathrm{L}^{3}}{4 b \mathrm{~h}^{3} \Delta \mathrm{d}}\left(\mathrm{Kg} / \mathrm{cm}^{2}\right)
$$

dengan :

MOE = Modulus of Elasticity/ Modulus lentur $\left(\mathrm{kg} / \mathrm{cm}^{2}\right)$

$\mathrm{P} \quad=$ beban pada batas proporsional $(\mathrm{kg})$

$\mathrm{L} \quad=$ jarak antar tumpuan $(\mathrm{cm})$

$\mathrm{b} \quad=$ lebar benda uji $(\mathrm{cm})$

$\mathrm{h} \quad=$ tebal benda uji $(\mathrm{cm})$

$\mathrm{d} \quad=$ Lenturan pada batas proporsional $(\mathrm{cm})$

\section{METODA}

Penelitian pemeriksaan bahan dan penelitian pengujian kekuatan lentur pelat ferosemen akan dilakukan di Laboratorium Bahan Puslitbang Permukiman Jalan Panyaungan Cileunyi Wetan, Kab. Bandung.

Metode penelitian yang digunakan dalam penelitian ini adalah metode penelitian eksperimen di laboratorium dengan benda uji ferosemen dan lembaran aluminium. Dalam penelitian ini peneliti menentukan populasi yaitu benda uji pelat beton ferosemen dengan panjang $1100 \mathrm{~mm}$, lebar $300 \mathrm{~mm}$, dan tebal $50 \mathrm{~mm}$. Serta lembaran aluminium dengan panjang $1100 \mathrm{~mm}$, lebar $300 \mathrm{~mm}$, dan tebal 0,3 mm. Sedangkan sampel penelitian yang 
digunakan adalah adalah benda uji berbentuk pelat sebanyak 15 benda uji dengan 3 kelompok proporsi campuran yang masing-masing menggunakan FAS 0,45.

Tabel 2. Campuran Pelat Ferosemen

\begin{tabular}{|c|c|c|}
\hline Campuran & Jumlah & FAS \\
\hline $1 \mathrm{PC}: 2 \mathrm{Ps}$ & 5 & 0,45 \\
\hline $1 \mathrm{PC}: 3 \mathrm{Ps}$ & 5 & 0,45 \\
\hline $1 \mathrm{PC}: 4 \mathrm{Ps}$ & 5 & 0,45 \\
\hline
\end{tabular}

Untuk lebih jelasnya, bentuk benda uji dapat dilihat pada gambar berikut,

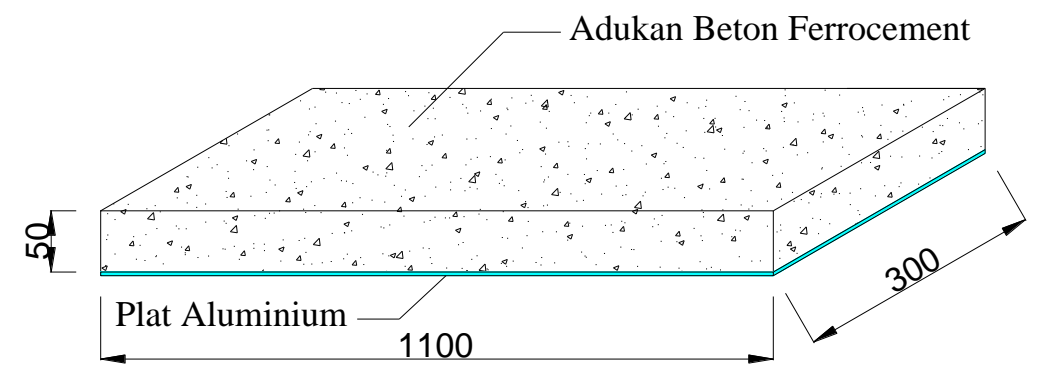

Gambar 2 Benda Uji Ferosemen

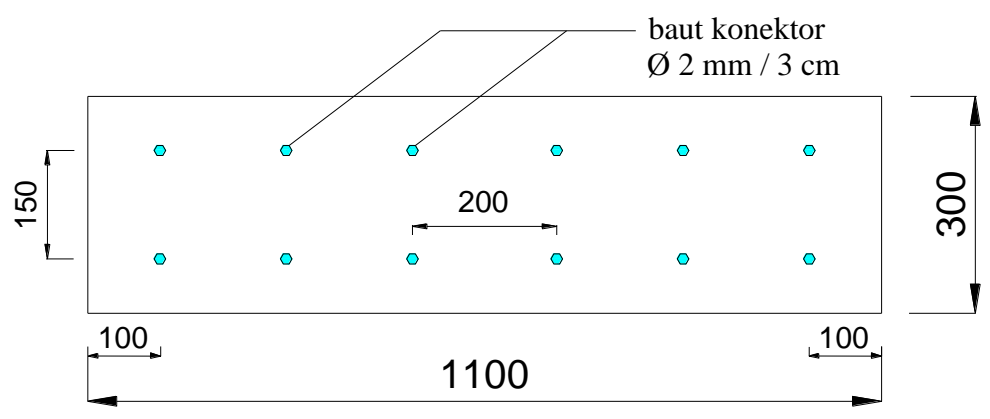

Gambar 3 Denah perletakan baut konektor pada aluminium dan ferosemen 
Pengujian yang dilakukan adalah pengujian kuat lentur dan modulus elsatisitas beton ferosemen. Peralatan yang digunakan pada pengujian ini adalah Mesin uji kuat lentur Electromechanical Flexural Testing Machine Merk Multiensayo Kapasitas 20 KN beserta perlengkapannya untuk mengetahui adanya lentur pada beton akibat adanya beban luar.

Pengujian dilakukan pada tumpuan sederhana sendi - rol dengan satu titik pembebanan di tengah-tengah bentang. Proses pengujian harus secara perlahan pada saat pemberian beban sampai pada benda mencapai batas maksimum dalam menerima beban sehingga dapat diketahui nilai beban yang diberikan.

Pencatatan benda uji yang bekerja dan defleksi (lendutan) yang terjadi pada model benda uji dilakukan setiap kelipatan beban $50 \mathrm{kgf}$. Pencatatan dilakukan pada nilai kuat tekan benda uji yang bekerja dan nilai defleksi (lendutan) yang terjadi di tengah-tengah bentang benda uji. Pengamatan selesai dilakukan apabila crack telah timbul, atau ditandainya dengan penurunan jarum penunjuk benda uji.

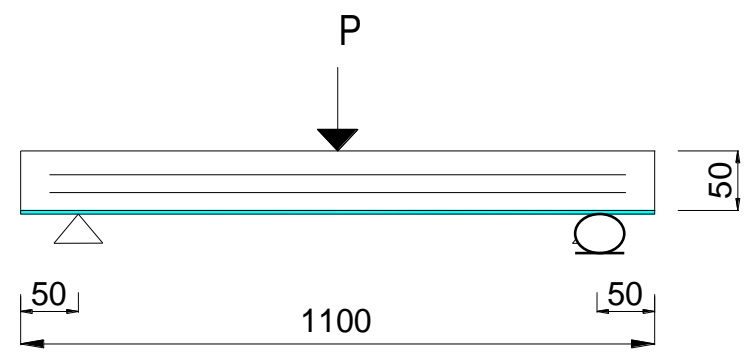

Gambar 4. Model Pengujian Kuat Lentur

\section{HASIL DAN PEMBAHASAN}

\section{Deskripsi Data}

Dari pengujian berat jenis dan penyerapan air agregat halus diperoleh hasil bahwa berat jenis SSD dari pasir beton yang digunakan adalah 2,44. Sedangkan kadar air yang terkandung dalam pasir tersebut adalah $13,16 \%$ dan penyerapan air pada agregat halus adalah $8,14 \%$. Dari hasil analisis saringan, diketahui bahwa gradasi dari pasir beton yang digunakan terletak pada zona gradasi 2, sehingga dapat dikatakan gradasi pasir beton 
yang digunakan adalah tidak terlalu halus dan tidak terlalu kasar. Berikut nilai slump masing-masing campuran ferosemen,

\section{Hasil Pengukuran BeratPelat Ferosemen}

Untuk mengetahui berat per volume dari pelat beton ferosemen dengan bekisting aluminium, maka akan diambil rata-rata dari berat pelat beton ferosemen dari keseluruhan benda uji yang ditimbang dan kemudian dibagi dengan volume benda uji.

Tabel 3. Hasil Penimbangan Pelat Ferosemen dengan bekisting aluminium ukuran $50 \mathrm{~mm} \times 300 \mathrm{~mm} \times 1100 \mathrm{~mm}$

\begin{tabular}{|c|c|c|c|}
\hline \multirow{2}{*}{ No. } & 1 PC : 2 Ps & 1 PC : 3 Ps & 1 PC : 4 Ps \\
\cline { 2 - 4 } & Berat (kg) & Berat $(\mathbf{k g})$ & Berat $(\mathbf{k g})$ \\
\hline $\mathbf{l}$ & 35,900 & 34,000 & 32,600 \\
\hline $\mathbf{2}$ & 33,500 & 34,800 & 32,500 \\
\hline $\mathbf{3}$ & 33,700 & 34,400 & 35,700 \\
\hline $\mathbf{4}$ & 33,100 & 34,600 & 33,400 \\
\hline $\mathbf{5}$ & 33,100 & 35,700 & 32,700 \\
\hline Berat Rata2 & 33,860 & 34,700 & 33,380 \\
\hline B.p.Volume & $\mathbf{2 . 0 5 2}$ & $\mathbf{2 . 1 0 3}$ & $\mathbf{2 . 0 5 0}$ \\
\hline
\end{tabular}

Tabel 4. Nilai Slump Ferrocement dengan Faktor Air Semen (FAS) 0,45

\begin{tabular}{|c|c|c|c|c|c|}
\hline \multirow{2}{*}{ No } & \multirow{2}{*}{$\begin{array}{c}\text { Perbandingan } \\
\text { campuran }\end{array}$} & $\begin{array}{c}\text { Bacaan 1 } \\
(\mathbf{c m})\end{array}$ & $\begin{array}{c}\text { Bacaan 2 } \\
(\mathbf{c m})\end{array}$ & $\begin{array}{c}\text { Bacaan 3 } \\
(\mathbf{c m})\end{array}$ & $\begin{array}{c}\text { Rata-rata } \\
(\mathbf{c m})\end{array}$ \\
\cline { 3 - 6 } & 1 & 12 & 10 & 11 & 11 \\
\hline 2 & $1 \mathrm{PC}: 2$ Ps $: 3$ Ps & 8 & 7 & 6 & 7 \\
\hline 3 & 1 PC $: 4$ Ps & 10 & 9 & 11 & 10 \\
\hline
\end{tabular}

Hasil Pengujian Kuat Lentur (Modulus of Rupture) dan Modulus Elastisitas Ferosemen 
Dari pengujian kuat lentur dan modulus elastisitas beton ferosemen dengan lapisan lembaran aluminium sebagai bekisting tetap dengan 3 variasi campuran didapat nilai kuat lentur dan modulus elastisitas pada Grafik 5 dan Grafik 6.

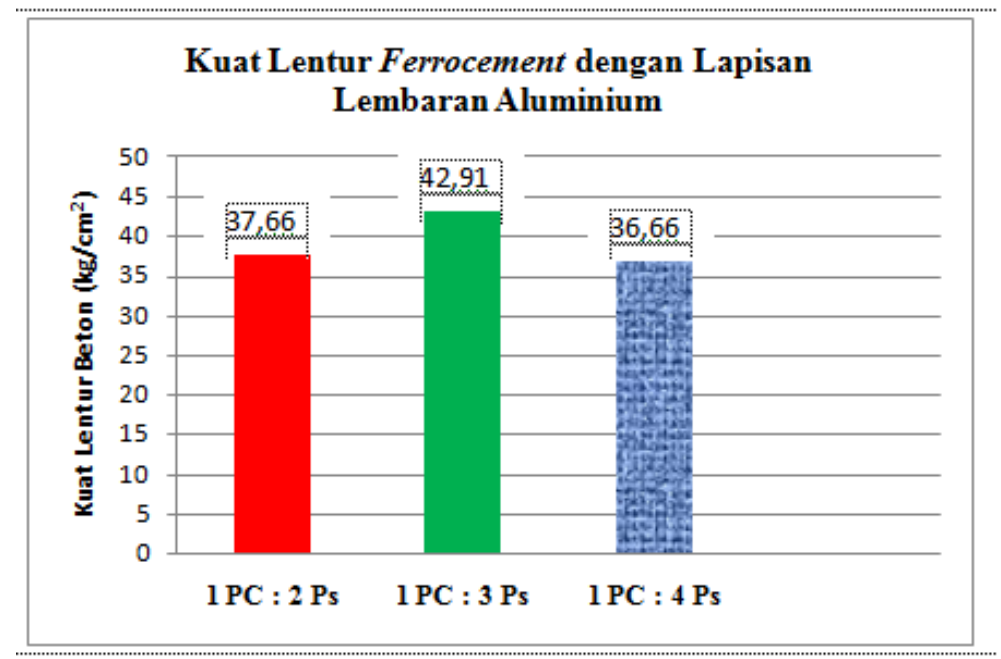

Gambar 5. Grafik kuat lentur pelat ferosemen dengan menggunakan lembaran aluminium sebagai bekisting tetap

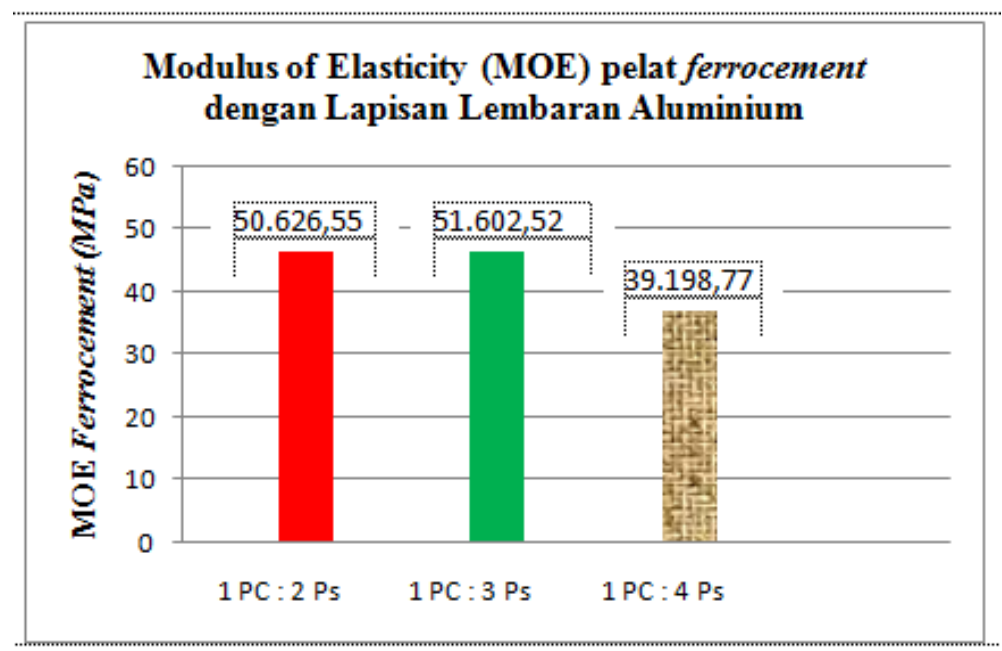

Gambar 6. Modulus elastisitas pelat ferosemen dengan menggunakan lembaran aluminium sebagai bekisting tetap 
Dari gambar 5 dan gambar 6 , tingginya nilai kuat lentur dan modulus elastisitas beton ferosemen pada campuran 1 PC : 3 Ps selain dipengaruhi oleh komposisi perbandingan semen dan pasir juga dapat disebabkan karena hasil dari nilai slump yang kecil. Campuran ferosemen 1 PC : 3 Ps memiliki nilai slump rata-rata paling kecil yaitu sebesar $7 \mathrm{~cm}$ dibandingkan dengan campuran yang lain. Nilai slump beton dapat mempengaruhi nilai kuat tekan beton, dimana semakin kecil nilai slump beton maka nilai kuat tekan beton semakin meningkat, dan nilai kuat lentur serta modulus elastisitas beton akan semakin meningkat seiring dengan meningkatnya nilai kuat tekan beton.

\section{KESIMPULAN}

Dalam pengujian kekuatan lentur pelat beton ferosemen dengan lapisan lembaran aluminium sebagai bekisting tetap ini dapat diambil kesimpulan bahwa hasil pengujian pelat ferosemen terbaik terdapat pada benda uji pelat ferosemen yang menggunakan perbandingan campuran $1 \mathrm{PC}: 3$ Ps dengan nilai kuat lentur sebesar $42,91 \mathrm{Kg} / \mathrm{cm}^{2}$ dan nilai modulus elastisitas sebesar $51.602,52 \mathrm{Kg} / \mathrm{cm}^{2}$ serta nilai slump beton sebesar $7 \mathrm{~cm}$.

\section{DAFTAR PUSTAKA}

Abdullah. 1999. "Ferosemen Sebagai Alternatif Material Untuk Memperkuat Kolom Beton Bertulang". Seminar on Air-PPI Tokyo Institute of Yechnologi 1999-2000 No.1 hal. 143-147

American Concrete Institute. 1993. "Guide fro The Design, Construction \& Repair for Ferrocement". ACl Commite 549.1R-93. New York : American Concrete Institute.

Anonymous, 1978, Ferrocement, Bandung: Puslitbang Jalan Departemen Pekerjaan Umum,.

American Standard Testing Material. 1994. "Standard test Method for Flexural Strenght of Concrete (Using Simple Beam With Center-Point Loading)".ASTM Commite C-9.

Badan Standar Nasional. Pengujian Berat Jenis Semen Agregat Halus. Diakses pada 3 November, 2011 dari www:http//bsn.go.id

Djausal, Anshori. Ferrocement. Diakses pada 15 Maret, 2012 dari World Wide Web:http://library.unila.ac.id/ans/index.php.

Hafizh, Abdul dkk. 2009. "Aluminium Murni dan Paduannya". Bogor: Departemen Teknik Pertanian, Institut Pertanian Bogor.

Mulyono, Tri. 2003. Teknologi Beton. Jakarta: Andi Yogyakarta 
P.C Sharma dan V.S Gopalaratman. Ferrocement Grain Stronge bin. Bangkok: International Ferrocement Information Center, 1997.

Raini, Yeni. 2011. "Pemanfaatan Limbah Styrofoam dan Limbah Serbuk Kayu Dengan Penambahan Serat Eceng Gondok Sebagai Material Komposit Dalam Pembuatan Papan Partikel". Palembang: Porseni BUMN 2011

Septiandini, Erna. 2007. "Rencana Program Kegiatan Pembelajaran Semester (RPKPS) dan Bahan Ajar Mata Kuliah Praktek Uji Bahan, Prodi S1 Teknik Sipil, Fakultas Teknik, Universitas Negeri Jakarta". Jakarta : Teknik Sipil Universitas Negeri Jakarta.

Setiyarto, Djoko Y. 2007. "Penggunaan Ferrocement dan Pelat Seng Sebagai Material Pelat Lantai Bangunan Bertingkat untuk Menekan Biaya Konstruksi". Bandung: Teknik Sipil Unikom.

Standar Nasional Indonesia. 2002. Metode, Spesifikasi, dan Tata Cara Edisi Pertama. Jakarta: Departemen Pekerjaan Umum

Sulaeman. 2005. "Studi Pengujian Kuat Lentur Pelat Beton Ferrocement dengan Tambahan Serat Fiber Polyamide". Jakarta: Teknik Sipil Universitas Negeri Jakarta 